\title{
Geology of the
}

Mount Fairplay Area Alaska

By HELEN L. FOSTER d

AONTRIBUTIONS TO GENERAL GEOLOGY $\rtimes$ GE OLOGICAL S URVEY B ULLE T I N $1241-\mathrm{B}$ A

A description of the geologic formations 4 and physiographic features of the Tanacross $C-3$ and $D-3$ quadrangles, in an rarea that has long been of interest to $\rightarrow$ prospectors

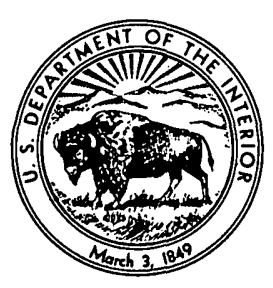


UNITED STATES DEPARTMENT OF THE INTERIOR

STEWART L. UDALL, Secretary

GEOLOGICAL SURVEY

William T. Pecora, Director 


\section{CONTENTS}

Abstract._...

Introduction................. 1

Bedrock geology

Metamorphic rocks............ 3

Birch Creek Schist._... 3

Metamorphic rocks of the West Fork vicinity

Sedimentary rocks-_.............. 5

Igneous rocks . . . .

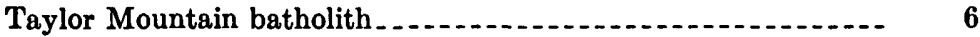

Mount Fairplay intrusive

Other intrusive rocks.......... 8

Volcanic rocks.

Mount Fairplay and vicinity

West Fork vicinity

Surficial geology....

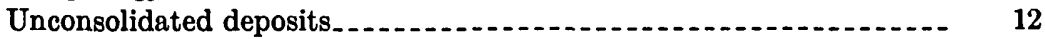

Frost features_...

Permafrost. ...

Pingos. . . . .

Frost debris. . . .

Structure...

Geomorphic surfaces.

Geologic history

Engineering and economic geology

References.................. 18

\section{ILLUSTRATIONS}

Plate 1. Geologic map of Mount Fairplay area, Alaska 



\title{
CONTRIBUTIONS TO GENERAL GEOLOGY
}

\section{GEOLOGY OF THE MOUNT FAIRPLAY AREA, ALASKA}

\author{
By Helen L. Foster
}

\begin{abstract}
The Mount Fairplay area is in the maturely dissected Yukon-Tanana Upland of eastern interior Alaska. The oldest bedrock is a complex group of metamorphic rocks, most of which are included in the Birch Creek Schist. The metamorphic rocks are intruded by granodiorite of Mesozoic age and syenite of Tertiary(?) age. Poorly exposed Cretaceous(?) strata lie between bands of metamorphic rocks north of Mount Fairplay. Tertiary (?) volcanic rocks encircle the syenite intrusive of Mount Fairplay and intrude and overlie the metamorphic rocks.

Unconsolidated deposits in the Mount Fairplay area are primarily alluvium, colluvium, and small amounts of loess and windblown ash. Frost features, including pingos, are common. Flat-topped ridges and flat to gently sloping benched surfaces are prominent above 3,500 feet altitude.

No minerals of economic signiflcance have been discovered in the Mount Fairplay area.
\end{abstract}

\section{INTRODUCTION}

The Mount Fairplay area, Alaska (Tanacross C-3 and D-3 quadrangles, scale 1:63,360, U.S. Geol. Survey Topog. Map series) is entirely within the Yukon-Tanana Upland, a maturely dissected, hilly to mountainous region between the Yukon and Tanana Rivers in eastern interior Alaska (fig. 1). Average relief is less than 1,500 feet. The area has not been glaciated.

The earliest recorded work in the Mount Fairplay area was done by Brooks (1900) in 1898 when he traveled from the mouth of the Tetlin River north to Eagle. In 1905 Prindle (1909) traversed parts of the area. The principal geologic work in the Yukon-Tanana Upland, including the Mount Fairplay area, was by Mertie from 1911 to 1931 (Mertie, 1937).

This report is a result of basic geologic field studies done on behalf of the Office of the Chief of Engineers, U.S. Army, and other Department of Defense organizations. Fieldwork consisted of a 10-day reconnaissance in August 1961 and more detailed reconnaissance in 


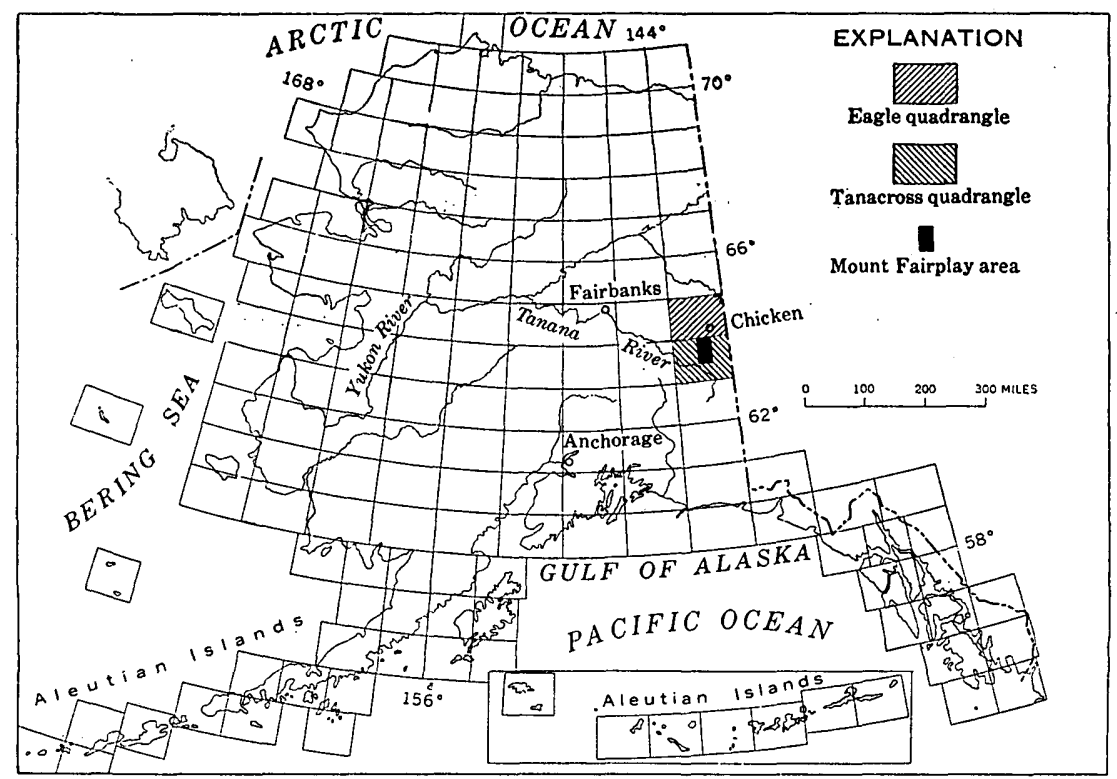

Frgure 1.-Index map of Alaska showing location of the Mount Fairplay area (15-minute Tanacross C-3 and Tanacross D-3 quadrangles).

June, July, and August, 1962. A few places were checked by helicopter in 1963. Mrs. Mona G. Carpenter assisted the author in the field in 1961 and 1962 and also assisted in the petrographic study of the volcanic rocks. Miss Beverly Marsters was the field assistant during the summer of 1963 . Field support, including helicopter, by Fort Greely in 1961, 1962, and 1963 is gratefully acknowledged. Helicopter transport in 1963 was furnished by the 80th Transportation Company from Fort Richardson and the 65th Transportation Company from Fort Wainwright. The helpfulness of the Marvin Warbelow family at their lodge on the Alaska Highway where the field parties headquartered is also acknowledged with thanks.

\section{BEDROCK GEOLOGY}

The oldest bedrock exposed in the Mount Fairplay area is a complex group of metamorphic rocks, which are dominantly quartz-biotite gneiss and schist. The metamorphic rocks are intruded by granodiorite, syenite, and other granitic rocks, the largest areas of which are in the vicinities of Taylor Mountain and Mount Fairplay (pl. 1). Poorly exposed Cretaceous(?) strata lie between bands of metamorphic rocks along the West Fork and in the southern part of the mapped area. Tertiary(?) volcanic rocks encircle the Mount Fairplay intrusive and overlie and intrude the metamorphic rocks. 


\section{METAMORPHIC ROCKS}

The metamorphic rocks of the Mount Fairplay area are tentatively divided into two groups. The most extensive group, which crops out in the Tanacross C-3 quadrangle and in the southern part of the D-3 quadrangle, is dominantly quartz-biotite gneiss and quartz-biotite schist; considerable augen gneiss and some amphibolite are also present. The second group crops out in an eastward-trending strip in the West Fork vicinity and consists principally of white and pink marble, impure green marble, quartzite, and limy quartzite. Mertie (1937, p. 46-47) mapped the rocks of both groups as Birch Creek Schist. In the present report, the first and most extensive group is designated as the Birch Creek Schist; the second group is referred to as the metamorphic rocks of the West Fork vicinity.

\section{BIRCH CREEK SCHIST}

The Birch Creek Schist in the Mount Fairplay area varies in degree of schistosity from outcrop to outcrop; in places the rock is a schist and elsewhere a gneiss, with many gradations between. Most of the gneiss and the schist are composed principally of quartz and biotite. The biotite ranges from very little to abundant; feldspar is generally sparse. Other common minor constituents include allanite, muscovite, sericite, apatite, and opaque iron oxides and sulfides. The quartz-biotite gneiss grades into quartz gneiss and quartz schist. As Mertie noted (1937, p. 49), the original detrital fabric and other evidence of sedimentary origin are still preserved in some rocks.

The most abundant type of augen gneiss has perthitic feldspar porphyroblasts 1-2 inches long. Brown biotite ranges from sparse to abundant. Quartz is a major constituent, but quartz augen are scarce. Opaque iron oxides and sulfides, apatite, and garnet are common accessories. Variations in the augen gneiss in the mapped area are mostly in the size of augen and the amount of biotite. Mertio (1937, p. 198-199) considered the augen gneiss as part of the Pelly Gneiss and believed that it was intruded into the Birch Creek Schist before the schist was metamorphosed. In the Mount Fairplay area the augen gneiss appears to be stratigraphically between quartz-biotite gneiss and amphibolite. In places the amphibolite is above the augen gneiss and the quartz-biotite gneiss (or schist) below; at other localities the apparent order of succession is reversed, and the reversal indicates that some sections are overturned.

Locally, actinolite schist and epidote-tremolite schist crop out, as on the ridge on the west side of Dennison Fork in the central part of the Tanacross D-3 quadrangle. Dark-gray quartzite, quartz schist, muscovite schist, sericite schist, garnetiferous biotite schist, horn- 
blende-garnet schist, and several kinds of gneiss, including a spotted gneiss with hornblende segregations and cataclastic gneiss, have also been found. Milky quartz veins, veinlets, and pods are numerous; most are parallel to foliation, but some cut across it.

The age of the Birch Creek Schist in the Mount Fairplay area and the Yukon-Tanana Upland is not known. Mertie believed it to be older than the Precambrian Tindir Group (Mertie, 1937, p. 56), but it is now thought that the Birch Creek Schist of the Yukon-Tanana Upland is separated from the Tindir Group by a major fault; therefore, Mertie's dating cannot be used. Isotopic age measurements of metamorphic rocks north of the Mount Fairplay area (Eagle quadrangle) indicate only that local metamorphism was contemporaneous with plutonic activity during the interval between 120 and 180 million years (Wasserburg and others, 1963, p. 259). Because the locality between the Mount Fairplay area and the isotopically dated rocks has not been mapped in detail, these isotope dates are not directly applicable to the Mount Fairplay area. The age of the Birch Creek Schist in the Mount Fairplay area may be Precambrian or early Paleozoic.

\section{METAMORPHIC ROCKS OF THE WEST FORK VICINITY}

Marble, quartzite, and quartzo-feldspathic hornfels crop out between Cretaceous(?) sedimentary rocks and the Taylor Mountain batholith in a few small scattered exposures east of Taylor Highway and in the bluff along the West Fork west of the highway. Elsewhere their presence is indicated only by float. The hornfels was found near highly altered and sheared porphyritic granitic rock that might be either part of the Taylor Mountain batholith or of some older intrusion. It is pink and green, is fine grained, and is composed principally of quartz and feldspar but includes biotite, some sphene, and opaque iron oxides and sulfides.

Most of the marble is white or pink but has local dark-gray streaks or spots. Some beds of impure green marble and limy quartzite are also present. Grain size ranges from fine to coarse. The quartzite is tan or gray and fine to medium grained, and some contains small amounts of feldspar, biotite, and iron oxides and sulfides. Sulfide minerals, commonly small pyrite crystals, are abundant in all these rocks except some of the marble. Irregular networks of calcite and quartz veinlets are numerous, particularly in the hornfels and the quartzite. All the rocks are intensely fractured, and many are highly sheared.

The northern contact of the metamorphic rocks with the Taylor Mountain batholith is not exposed. The southern contact with the 
sedimentary and associated volcanic rocks is exposed only at one locality and is a fault between lava, hornfels, and quartzite.

The age of the metamorphic rocks of the West Fork vicinity is unknown. They resemble the metamorphic rocks a few miles to the north that Mertie (1937, p. 97) mapped as undifferentiated Devonian. They could also be a facies of the Birch Creek Schist different from that to the south.

\section{SEDIMENTARY ROCKS}

Interbedded conglomerate, sandstone, shale, siltstone, tuff, lignite, and chert are poorly exposed in a belt between the Birch Creek Schist and the metamorphic rocks of the West Fork vicinity in the Tanacross D-3 quadrangle. Rocks of similar lithology also occur along Taylor Highway in the southern part of the Tanacross $\mathrm{C}-3$ quadrangle. The thickest measurable sequence is about 62 feet thick, but on the basis of width of outcrop and dip, the formation is estimated to be at least 200 feet thick.

A weathered conglomerate containing a few beds of sandstone crops out at the base of the sedimentary rocks 1 mile east of Taylor Highway. The conglomerate is composed primarily of well-rounded white translucent quartz pebbles, some pebbles of Birch Creek Schist, and a few pebbles of greenish-gray lava in an arkosic, slightly micaceous matrix. Pebbles range from less than one-fourth inch to more than 2 inches in diameter. In places the matrix of the conglomerate and the interbedded sandstone resembles debris from weathered Birch Creek Schist and, thus, indicates that the material composing the conglomerate and sandstone was derived largely from weathering of the schist. The basal conglomerate is overlain by a succession of tan and gray beds of arkosic sandstone, quartzitic sandstone, tuffaceous sandstone, shale, tuffaceous shale, tuff, siltstone, conglomeratic tuff, conglomeratic sandstone, and conglomerate. Most of the beds are 1-6 inches thick, but some congolmeratic beds are as much as 3 feet thick. Many of the shales are highly carbonaceous, contain plant remains, and have intercalated thin lignite beds. Some sandstone also has scattered carbonaceous material and plant impressions. A few beds of sandstone and shale contain limonite nodules, and secondary calcite coats many bedding planes and fracture surfaces. Fragments of gray, red, tan and banded gray and red chert were found in a borrow pit on the east side of Taylor Highway about 2 miles south of the West Fork bridge. The chert occurred along the strike of the sedimentary beds indicating that it is from an unexposed bed in the sedimentary sequence.

$244-802-67-2$ 
A puorly preserved palynomorph flora from two places, USGS Paleobot. loc. D1804-1, 2 in the section exposed along Taylor Highway about 3 miles south of the West Fork bridge contained the following fossils identified by Robert H. Tschudy (U.S. Geol. Survey, July 31,1962$)$ :

Aquilapollenites
Lycopodiumsporites
Taxodiaepollenites
conifer pollen (two kinds)
Cicatricosisporites
fern spores (two kinds)
Tasmanites?
Leiozonotriletes naumovae?
monosulcate pollen
tricolpate pollen.

Tschudy reported that many of the spores, including Tasmanites? and Leiozonotriletes naumovae?, indicate an Upper Devonian assemblage but that this assemblage is mixed with one of a more modern aspect, characterized by tricolpate, monosulcate, coniferous, and Aquilapollenites pollen. On the basis of the latter assemblage, an age of Late Cretaceous is suggested for these sedimentary rocks, but because of the poor preservation of the organic material, an even younger age cannot be ruled out.

Sedimentary rocks near Chicken, in the southern part of the Eagle quadrangle, to the north, are similar lithologically to those near the West Fork, but their palynomorph flora (USGS Paleobot. loc. D334547 ) indicates that they are probably Tertiary in age. Sedimentary rocks also similar to those near the West Fork have been found in the Tanacross B-3, B-5, C-2, and C-4 quadrangles. The palynomorph flora of those sedimentary rocks along the Tanana River in the B-5 quadrangle, USGS Paleobot. loc. D3510, indicates probable correlation with the West Fork sedimentary rocks.

\section{IGNEOUS ROCKS}

\section{TAYLOR MOUNTAIN BATHOLITH}

Granodiorite, which forms Taylor Mountain and which is part of a batholith covering about 250 square miles, crops out over an area of more than 100 square miles in the north half of the Tanacross D-3 quadrangle. The rock throughout most of the pluton is medium- to coarse-grained nearly equigranular granodiorite or adamellite, but in a few places, particularly near the southeastern margin along the West Fork, it is mostly quartz diorite and diorite. Locally the rock is peg- 
matitic. The interior of the pluton is structureless, but the rock is gneissic along the southern margin.

Plagioclase (oligoclase to andesine), sericitized potassium feldspar, quartz, and hornblende are the principal minerals of the granodiorite. Quartz, especially near the margin of the intrusion, is strained and fractured. Graphic intergrowth of feldspar with quartz occurs. Minor mafic constituents are biotite, some. of which has altered to chlorite, and augite and allanite. Opaque iron oxides and sulfides, apatite, sphene, and zircon are abundant accessories, and muscovite was noted in a few thin sections. The diorite consists of plagioclase, hornblende, biotite, chlorite, quartz, epidote, sericite, calcite, hematite, magnetite, apatite, and zoisite. Sphene also occurs in some diorite.

Xenoliths of Birch Creek Schist are abundant in places along the southern margin of the pluton and are well exposed in the north bank of the West Fork 0.3 mile west of the Taylor Highway bridge. The xenoliths range in size from less than one-half inch to many feet in diameter. The larger blocks of Birch Creek Schist megascopically show little or no effects of the intrusion, but some of the smaller fragments are partly absorbed. Dark segregations of mafic minerals which may be remnants of xenoliths are widely scattered throughout much of the intrusion.

Dikes of lamprophyre and other mafic rocks cut the granodiorite; and in some outcrops, stringers 1-5 inches wide of quartz and feldspar and a few dark minerals form a nearly rectangular pattern (average size about $2 \frac{1}{2}$ by $3 \mathrm{ft}$ ). The stringers are more resistant to weathering than the surrounding rock and so form a raised network. A lamprophyre, $10-12$ feet wide and striking N. $45^{\circ} \mathrm{E}$., is exposed in a small borrow pit along Taylor Highway at the northern margin of the Tanacross D-3 quadrangle. The dominant mafic mineral is biotite. The rock appears to have a crude vertical foliation parallel to the trend of the dike. A brecciated zone borders the dike on the southeast. Alongside the dike, the breccia dominantly consists of fragments of the dike rock surrounded by secondary quartz, but the rest of the breccia is mostly granitic fragments in quartz. Many voids occur in the breccia.

The single age measurement available on the granodiorite was made on rock collected along Taylor Highway in the southern part of the Eagle quadrangle about 3 miles north of the northern boundary of the Tanacross D-3 quadrangle. $\mathrm{Sr}^{87} / \mathrm{Rb}^{87}$ determinations on biotite gave an age of 190 million years (Wasserburg and others, 1963, p. 258).

\section{MOUNT FAIRPLAY INTRUSIVE}

A syenite stock about 7.5 square miles in area intrudes the Birch Creek Schist and forms part of Mount Fairplay. The stock is com- 
posed dominantly of hornblende-biotite syenite, but a little monzonite and adamellite are also found in the vicinity.

The syenite consists mainly of sericitized feldspar and has much less abundant mafic minerals. Microperthite and perthite are generally the most abundant constituents. The plagioclose is albite, oligoclase, or, less commonly, andesine. Potassium feldspars contain abundant dusty inclusions. Green hornblende and greenish-brown biotite are the principal mafic minerals, but diopside or diopsidic augite is commonly present as discrete grains or may occur as a core surrounded by hornblende. Apatite and opaque iron oxides and sulfides are abundant accessories; sphene and zircon are less abundant. Quartz generally makes up less than 1 percent of the syenite. Quartz crystals are commonly strained, and crystal boundaries may show granulation. Although graphic intergrowths rarely occur, hornblende in one monzonite exhibits graphic intergrowth with quartz and feldspar.

Texture and grain size vary widely in the syenite. Some syenite rocks are nearly equigranular and have an average grain diameter of about $1 / 8^{-1 / 4}$ inch. Some are porphyritic and contain bluish-gray potassium feldspar phenocrysts as much as 2 inches long. Needlelike hornblende phenocrysts $1 / 4-1 / 2$ inch long occur along the eastern contact with the schist.

The stock discordantly intrudes the Birch Creek Schist, and along the eastern contact some syenite dikes extend into the country rock. At the northeastern contact, below the highest point on Mount Fairplay, the syenite contains many partly, and some almost wholly, absorbed masses of augen gneiss. The northern and western contacts of the stock are covered but are probably faults, especially on the west. As inferred from rubble along the southern boundary, there is a contact zone $0.1-0.5$ mile wide in which the igneous rock grades from fine to coarse grained.

Matzko, Jaffe, and Waring (1958, p. 531) obtained a mean leadalpha-age of 103 million years on zircon from syenite collected near the southern margin of the stock. Using the $\mathrm{Sr}^{87} / \mathrm{Rb}^{87}$ method, Wasserburg and Eberlein (G. D. Eberlein, written commun., 1964) obtained an age of 69 million years from biotite collected at a different locality. On the basis of present geologic knowledge of the Mount . Fairplay area, either age is possible.

\section{OTHER INTRUSIVE ROCKS}

Granitic rubble, including granitic rocks uplifted in a pingo, in the south-central part of the Tanacross C-3 quadrangle may be derived from a small shallow igneous intrusion. The rock is mostly coarse- to medium-grained pink granite, but locally it is aplitic or porphyritic; 
in places the pink granite seems to grade into fine-grained porphyritic rock containing terminated quartz phenocrysts. The rock is principally composed of quartz and sericitized feldspar; graphic intergrowths of the two minerals are common.

Pegmatitic and granitic dikes, sills, and small stringers commonly cut the Birch Creek Schist in areas some distance from the margins of the known intrusions; they are best displayed in the southeastern part of the Tanacross D-3 quadrangle. The pegmatite is composed primarily of quartz, feldspar, and muscovite. Fine-grained granitic and aplitic dikes containing abundant biotite also occur. Cream-colored felsitic dikes are also abundant locally but generally not in the same areas as the granitic and pegmatitic dikes.

\section{VOLCANIC ROCKS}

\section{MOUNT FAIRPLAY AND VICINITY}

The volcanic rocks surrounding the Mount Fairplay intrusive are divided into (1) dominantly light-colored rocks of rhyolitic to dacitic composition and (2) dominantly dark-colored rocks of andesitic composition.

Most of the yolcanic rocks are poorly exposed, particularly the felsic rocks, which are highly fractured and broken into small fragments by frost action. The mafic rocks crop out more commonly in cliffs than the felsic rocks and, in places, occur as isolated tors on ridgetops. Many tuffs are well bedded and the beds are tilted. Locally, mafic dikes cut areas of dominantly felsic volcanic rocks. Patches of felsic volcanic rocks may occur in the midst of dominantly mafic volcanic rocks, and vice versa.

The felsic volcanic rocks consist of lava, tuff, tuffaceous sediments, tuff-breccia, breccia, and volcanic conglomerate. They are generally white, light gray, light green, light pink, or cream colored. Tuff, including welded tuff, is the most abundant rock type. The lava ranges from aphanitic to porphyritic in texture. Grain size in tuff ranges from very fine to very coarse, but some tuff has mixed fine and coarse grains. Much fine-grained tuff is -very uniform in texture and resembles chert or porcellanite. Coarse-grained tuffs are locally conglomeratic. Lapilli tuff, including tuff with concretionary lapilli, has been found, particularly on the northwestern flank of Mount Fairplay. Some tuff layers composed of silt-size grains grade to layers of sandsize grains, and some of these layers contain small amounts of nonvolcanic sedimentary material. Most of the breccia fragments are less than 1 inch in diameter, but locally, larger fragments either compose an overall coarse breccia or are scattered in a finer breccia. The breccia may be composed of either homogeneous or heterogeneous frag- 
ments of volcanic rock. Fragments of gneiss, schist, and quartzite are found in some volcanic and tuff-breccias and are widely scattered in tuff matrix. Fragments of granitic rocks have also been found, but they are scarce.

The felsic volcanic rocks are composed primarily of quartz and feldspar and minor amounts of biotite, amphibole, and pyroxene. Common accessory minerals are magnetite, ilmenite, hematite, pyrite, apatite, zircon, and allanite. Orthoclase is the common potassium feldspar; sanidine and anorthoclase are scarce. The plagioclase feldspar is generally oligoclase or andesine. Quartz phenocrysts are commonly well-terminated crystals of smoky quartz; however, some of the quartz phenocrysts are partly resorbed, particularly in welded tuffs. In many rocks considerable quartz can be detected in the groundmass. Spherulites occur in some specimens. Iron sulfides are locally very abundant, occurring as small metallic crystals or altered to form brown specks in the rock.

In welded tuffs the groundmass is a distinct brown, probably due to the internal reflection of light by shards. Commonly the shards are completely flattened and considerably drawn out. Some form narrow discontinuous bands that bend around phenocrysts. In places the shards appear to be squeezed between phenocrysts and into resorbed areas in quartz phenocrysts. Except for those outlined by iron oxide, most shards are not sharply defined. Some shards have not crystallized and are still glassy, but others are composed of several crystals. In many welded tuffs, quartz crystals are coarser in the shards than in the surrounding area. Where the shards have been flattened and drawn out, areas of crystallization seem to pass through the shards and to be continuous with areas of crystallization in the surrounding material.

Most of the felsic volcanic rocks are considerably altered. The feldspars are in part altered to sericite and kaolinite. Biotite is generally completely altered to chlorite, epidote, or both. Leucoxene or sphene is also present. Amphibole commonly shows alteration similar to biotite; however, some has remained fairly fresh or is outlined by opaque iron oxide. Locally the groundmass still has its original texture, but elsewhere the original texture has been obliterated by secondary crystallization.

The largest deposit of felsic tuff is northwest of Mount Fairplay and covers an area of about 70 square miles. Gray rhyolitic welded tuff is the most abundant and widespread type. The welded tuff megascopically resembles lava and is characterized by an abundance of well-terminated smoky quartz phenocrysts. Felsic volcanic rocks south of Mount Fairplay include a similar-appearing fairly widespread welded tuff, but thin-section examination indicates that this tuff 
is distinct from the one to the north. The southern tuff has a lower percentage of quartz phenocrysts and more plagioclase phenocrysts, and it contains allanite and zircon.

About 6 miles west of the top of Mount Fairplay, a deposit of tan and pink pumice is exposed in a bluff. The pumice in the lower 20 feet of the exposure is slightly welded and not distinctly bedded. Beds of green and white tuff form ledges in the upper part of the exposure. In the green tuff, grain size grades from fine at the base of individual beds to coarse at the top. Above the bedded tuff the pumice is coarse, partly welded, and contains fragments of Birch Creek Schist. Volcanic breccia containing large white pumice fragments also makes up part of the deposit. The green tuff beds strike N. $70^{\circ} \mathrm{W}$. and $\operatorname{dip} 35^{\circ} \mathrm{SW}$.

In several localities light-colored volcanic rocks without quartz phenocrysts occur. They have abundant plagioclase phenocrysts but fow mafic ones (altered biotite or amphibole). Some have siliceous aggregates in the groundmass. Most of the plagioclase phenocrysts are strongly zoned. Some areas where these rocks occur are indicated on plate 1 by symbol.

The mafic volcanic rocks consist chiefly of lava, breccia, and tuff. They are generally dark gray, dark greenish gray, or dark maroon. Lava is more abundant than in the felsic rocks. The mafic volcanic rocks range in texture from uniformly fine grained to coarsely porphyritic. A few lavas are vesicular or amygdaloidal.

Phenocrysts are plagioclase, biotite, amphibole, pyroxene, or pseudomorphs after pyroxene. Most of the plagioclase is zoned, and the interior of crystals are more calcic than the margins. Opaque iron oxides and sulfides are common accessories. Plagioclase has commonly altered to sericite and carbonate. Biotite and amphibole have altered to chlorite, epidote, leucoxene, and sphene. Commonly, carbonate minerals have wholly or partly replaced pyroxene.

Of the mafic specimens examined, only one was basalt. It was collected in the northeastern part of the Tanacross C-3 quadrangle and is probably from a dike. The basalt has completely serpentinized crystals of olivine and a few pyroxene crystals in a fine-grained groundmass of plagioclase crystals.

The volcanic rocks surrounding Mount Fairplay are tentatively considered Tertiary in age because of the following indirect evidence. Glass is still evident in many lavas and tuffs, although considerable devitrification has taken place. Fragments of Birch Creek Schist are locally abundant in lavas, and fragments of granitic rocks were found in two localities. Stratigraphic relations indicate that the felsic volcanic rocks are at least as young or younger than the syenite from 
Mount Fairplay. Nearly all the volcanic rocks are well indurated, probably folded, and considerably eroded.

The mafic volcanic rocks may be slightly younger than the felsic volcanic rocks. In places mafic lava, other than small dikes, appears to have intruded felsic rocks, but exposures are not good enough to determine this relation with certainty. In other parts of the Tanacross quadrangle, outside the Mount Fairplay area, the youngest volcanic rocks are mafic.

\section{WEST FORK VICINITY}

Mafic volcanic rocks are closely associated with the Cretaceous(?) sedimentary rocks that crop out in the vicinity of the West Fork. On the north side of the West Fork, the mafic rocks overlie a section of sedimentary rocks exposed in the river bluff. The volcanic rocks are mostly porphyritic hornblende andesite; some are hornblende-biotite andesite. In another locality to the east, on the south side of the West Fork, dark-colored fine-grained highly fractured lava is found in contact with sedimentary rocks and in fault contact with metamorphic rocks. Tuffaceous material is abundant in the sedimentary rocks adjacent to and underlying the mafic lavas. The volcanic rocks in the vicinity of the West Fork are all geographically separated from those around Mount Fairplay, and their relation to the Mount Fairplay volcanic rocks is not known.

\section{SURFICIAL GEOLOGY}

\section{UNCONSOLIDATED DEPOSITS}

The unconsolidated deposits in the Mount Fairplay area are primarily alluvium, colluvium, and small amounts of loess and windblown ash. Most ridgetops are covered with residual soil or rock debris.

The largest flood-plain and low terrace (terraces $5 \mathrm{ft}$ or less above present normal stream level) deposits are along the West Fork, two of its tributaries, and the Dennison Fork. The deposits consist primarily of well-stratified layers and lenses of sand and gravel, but locally silt predominates. Some silt deposits contain considerable organic matter. Depressions on the flood plains, such as old oxbows, are filled or partly filled with peat and other organic matter. In most small tributary stream valleys in the southern and eastern parts of the Tanacross C-3 quadrangle, the deposits are dominantly silty. Some alluvium contains large boulders. Thickness of the floodplain alluvium varies. Alluvial fill along the West Fork in the Tanacross D-3 quadrangle is estimated to be less than 25 feet thick in most places. Alluvial fill in the Dennison Fork valley in the southeastern part of the C-3 quadrangle and in the tributary to the West Fork in 
the northwestern part of the $\mathrm{C}-3$ quadrangle is probably more than 50 feet thick in places.

High terrace (terraces $5 \mathrm{ft}$ or more above present normal stream level) deposits are principally along the West Fork and the Dennison Fork up to altitudes of 2,100 feet and more than 200 feet above the present stream. High stream terraces are not as well formed in the Mount Fairplay area as they are along the Forty Mile River and its branches to the north in the Eagle quadrangle. The terrace deposits, like the present flood-plain deposits, consist primarily of gravel and sand. They are crudely stratified and are poorly to well sorted. Where thickness could be determined, the terrace deposits generally ranged from 1 to 15 feet in thickness, but some are probably thicker. A typical terrace deposit along the Dennison Fork consists of about 10 feet of coarse poorly stratified gravel overlain by 3 feet of gray laminated silt. Terraces of small tributary streams are commonly of sandy silt and stony stratified silt.

Small alluvial fans occur in many places throughout the Mount Fairplay area, and a group of fairly large coalescing alluvial fans cover the eastern slopes of Mount Fairplay. Most fan material is considerably mixed with colluvium and ranges in size from large boulders to silt. In general, stratification is not well defined. Most of the boulders, cobbles, and pebbles are only slightly rounded.

Colluvium, consisting of variable mixtures of loess, talus, alluvium, and bedrock fragments, occurs throughout the Mount Fairplay area and along with mixtures of residual material and some wind-deposited material conceals much of the bedrock, particularly in the southern part of the Tanacross C-3 quadrangle. Colluvium is also present on many of the higher mountain slopes, and rubble covers many ridge crests. Coarse gravity-moved rubble is especially well exposed on the east side of Mount Fairplay below the summit. On the lower parts of many slopes, colluvium becomes mixed with alluvium and grades into alluvial deposits on the valley bottom.

Locally, thin deposits of loess are present in the Mount Fairplay area, but they are relatively insignificant. A thin irregular deposit of light-gray volcanic ash lies just below the turf on many ridgetops. Ash was also found in a few places in stream valleys, where it is buried by several feet of recent accumulations of silt. The volcanic ash is generally 1-4 inches thick but, in places, is scarcely recognizable because of mixture with other materials. The ash is probably the same as that which covers a wide area in eastern Alaska and the southern Yukon Territory and which has been mapped and described in detail by Bostock (1952), Capps (1916), and others. On the basis of radiocarbon dates from layered peat deposits above and below the ash in the 
upper Tanana River valley, Fernald (1962), indicated that the ash fell between 1,750 and 1,520 years B.P. (Before Present).

\section{FROST FEATURES}

\section{PERMAFROST}

Permafrost is present throughout most of the Mount Fairplay area, although this part of Alaska is in the zone of discontinuous permafrost. In fine-grained material, permafrost is commonly found at depths of 2 or 3 feet. In coarse-grained material, it is generally deeper, about 10 feet. The thickness of permafrost is estimated to range from a few tens of feet to about 200 feet. Ice lenses 15 or more feet long having exposed thicknesses of 5 or 6 feet have been seen in alluvial silt along several small stream valleys. They were actively melting in summer and causing collapse along the margins of the stream. The valley floor of the Dennison Fork in the southeastern part of the Tanacross C-3 quadrangle has numerous small patches of ice-wedge polygons formed in permafrost.

\section{PINGOS}

A dozen pingos (large mounds raised by the growth of ground ice) are known in the Tanacross C-3 quadrangle, and one has been mapped in the D-3 quadrangle. They are all of the open-system type (Holmes and others, 1963). These pingos, like those in other parts of interior Alaska, are usually on gentle south-facing slopes and are most prevalent on the upslope margin of the valley alluvial deposits.

A cluster of four pingos occurs in the southwestern part of the C-3 quadrangle in thick colluvial and alluvial material. The pingos are comparatively low, about 35 feet or less in height, except for one, which rises to about 70 feet on one side. None of these pingos have craters although one has an amphitheater-shaped depression and an area where fairly recent slumping and disruption have taken place. Water emerges from the disrupted part.

The six pingos along the valley 7 miles to the north of the cluster differ from those in the cluster by having well formed central craters. Water partly fills the craters except for one which has a mound about 30 feet in diameter of broken and disrupted silt blocks rising from its center.

The principal differences between the two pingo groups are largely attributed to their different phases of growth or degeneration. Low, relatively smooth undisrupted pingos, such as No. 4 (see pl. 1), are considered to be in an early stage of growth or possibly to represent stability because the ice lens is neither growing nor melting. Pingo 3, whose top is broken by cracks and polygons, is probably still forming, although both pingos which are actively growing or those whose ice 
cores are melting may show slumping and disruption. Pingos are old when they have a permanent pond rimmed by low banks and gentle, well-vegetated stable slopes without cracks, frost polygons, or evidence of recent slumping or other disturbance. The ice core of such pingos-for example, No. 1-has probably melted. Some of the pingos which occur singly, such as No. 5, are compound, the more recently formed mound or mounds partly overlapping features that formed earlier. This overlapping indicates growth and subsequent degeneration of one or more ice lenses.

\section{FROST DEBRIS}

Residual debris formed by frost action on bedrock mantles many of the upland surfaces. In localities of granitic bedrock, rubble blocks are commonly several feet in diameter. Most blocks are lichen covered, and in places shrubs or small trees have become established among the rubble, evidence indicating that the rubble is not now forming. In localities of siliceous volcanic rock, the rubble is composed mostly of small flat fragments only a few inches long.

At higher altitudes, above 3,500 feet, frost action has produced patterned ground features in the rubble, including segregated rings, nets, loops, and stripes, or nonsegregated steps, lobes, spot medallions, and hummocks.

At lower altitudes, hummocks and tussocks are widely distributed, especially in bogs and marshes and on low relatively flat land where the timber has been removed. In such places the active layer, or depth of thawing in summer, is generally 2-3 feet.

\section{STRUCTURE}

Physiographic features, such as the trend of major stream valleys and the alinement of ridges, suggest major northeast-trending structural control in the bedrock of the Tanacross quadrangle. A less distinct northwest trend cuts the northeast trend at right angles, and the result is a roughly rectangular topographic map pattern. In the Mount Fairplay area, however, the pattern has been disrupted and obscured, probably by igneous intrusions and Tertiary (?) volcanic rocks. Thus, as might be expected, foliation (primarily due to orientation of tabular micaceous minerals and to segregation of certain minerals into layers) and minor fold axes in the Birch Creek Schist are diverse in strike and dip, and no pattern or structures could be delineated from the small number of outcrops. Because the area is complexly folded, however, local nearly horizontal planes of foliation are interpreted as occurring on limbs of large recumbent folds.

Folding in the Cretaceous(?) sedimentary rocks seems to reflect the northeast trend of structural control, although divergent strikes occur. 
Also, the outcrop pattern suggests infolding of a formerly more extensive cover of sedimentary rocks, together with the Birch Creek Schist, along east-west axes.

The Tertiary (?) volcanic rocks have also been deformed, as shown by steep dips in bedded volcanic tuffs. Some of the steep dips are attributed to faults and initial dip, and others to folding. The axes of folds could not be determined from the small number of outcrops.

All the rocks of the Mount Fairplay area are considerably fractured, and many areas of particularly severe crushing and shearing occur, especially in the vicinity of the West Fork. Mylonite and fault gouge indicate both old and young fault zones. Most mapped faults dip at high angles.

\section{GEOMORPHIC SURFACES}

In the vicinity of Mount Fairplay and around Taylor Mountain, flat-topped ridges and flat to gently sloping benched surfaces are conspicuous above 3,500 feet in the zone of tundra vegetation. Most of these surfaces are on Tertiary (?) volcanic rocks, but a few have formed on granitic and metamorphic rocks. Some are strongly benched; others are not. The benches vary in size but commonly are a few hundred feet square. The scarps between benches range in height from 5 to 50 feet and average about 20 feet. Most of the scarps expose bedrock and are not entirely made up of talus blocks, as are those of the solifluction terraces described by Eakin (1916, p. 79).

Some of the surfaces may have been produced by altiplanation as described by Eakin (1916, p. 78-82). This is particularly true of those surfaces around Taylor Mountain; others may be related to the deposition of welded tuffs and lava flows on relatively flat surfaces and to nearly horizontal sheeting in granitic rocks. Many of the flat ridgetops may be remnants of erosion surfaces formed after deposition, uplift, and folding of the volcanic rocks because some cut across dipping bedded tuffs in localities where good evidence of solifluction is lacking. In most places, a combination of processes probably produced the surfaces.

\section{GEOLOGIC HISTORY}

The first discernible geologic events in the Mount Fairplay area took place during one or more periods when the sediments and volcanic materials that compose the metamorphic rocks were deposited. Intervening geologic events, such as might be indicated by unconformities, have not yet been recognized. Igneous intrusions occurred and were followed by or were contemporaneous with regional metamorphism. The time of these events, including the first metamorphism, was pre-Jurassic. 
In Late Triassic or Early Jurassic time, the Taylor Mountain batholith was intruded. It disrupted the metamorphic rocks in places and produced local thermal effects along its margins.

Following uplift in Late Cretaceous(?) or early Tertiary time, the Birch Creek Schist and locally exposed rocks of Devonian age were eroded, and sediments were deposited subaerially, perhaps in local swampy depressions. Volcanic activity occurred contemporaneously.

Intrusion of the Mount Fairplay stock was probably the next Tertiary event. The intrusion was accompanied or followed by extensive volcanic activity, including the deposition of considerable welded tuff. During continued volcanic activity primarily andesitic lava and tuff were produced. Uplift and folding followed.

Probably in late Tertiary or early Pleistocene time, local high-level erosion surfaces were formed as a result of erosion and subsequent uplift. Through the Pleistocene and into the Recent,"minor changes, probably due to tilting, caused the formation of stream terraces by renewed downcutting of the major streams... Rubble and talus collected and were moved by gravity. Pingos and extensive alluvial fans formed. About 1,500-1,700 years: ago, a thin layer of windblown volcanic ash from a distant volcano to the southeast fell on the Mount Fairplay area. The ash has been partly removed by erosion, covered by and mixed with organic material, and in a few places buried by alluvial silt.

\section{ENGINEERING AND ECONOMIC GEOLOGY}

Engineering construction materials are not particularly abundant or of high quality in the Mount Fairplay area, but sufficient material is available for local road construction and fill. Colluvial deposits, volcanic rock fragments, and weathered granite have been used for road surfacing because of the lack of good and easily accessible gravel deposits.

In most uplands along Taylor Highway, bedrock has only 6 inches to 3 feet of overburden. Significant weathering effects are generally found only in the upper 3 feet of bedrock but may locally extend to 15 feet in granitic rocks. Some of the volcanic rocks, schists, and granitic rocks which are highly weathered or fractured are easily excavated, but others require blasting.

Gold or other minerals of economic importance or economic quantity have not been discovered in the Mount Fairplay area although prospectors have searched for them since the discovery of gold along the Forty Mile River in 1886 (Prindle, 1909, p. 34). Placer gold is still mined at Chicken, which is only a few miles north of the Mount Fairplay area. Uranium prospectors have searched, particularly on 
the slopes of Mount Fairplay and Taylor Mountain, but have not been successful. From a distance, bright orange-yellow lichens growing on some outcrops at higher altitudes have been mistaken for uranium minerals.

\section{REFERENCES}

Bostock, H. S., 1952, Geologg of the northwest Shakwak valley, Yukon Territory : Canada Geol. Survey Mem. 267, 54 p.

Brooks, A. H., 1900, A reconnaissance from Pyramid Harbor to Eagle City, Alaska, including a description of the copper deposits of the upper White and Tanana Rivers: U.S. Geol. Survey 21st Ann. Rept., pt. 2, p. 331-396.

Capps, S. R., 1916, The Chisana-White River district, Alaska : U.S. Geol. Survey Bull. 630, $130 \mathrm{p}$.

Eakin, H. M., 1916, The Yukon-Koyukuk region, Alaska : U.S. Geol. Survey Bull. $631,88 \mathrm{p}$.

Fernald, A.T., 1962, Radiocarbon dates relating to a widespread volcanic ash deposit, eastern Alaska, in Short papers in geology, hydrology, and topography : U.S. Geol. Survey Prof. Paper 450-B, p. B29-B30.

Holmes, G. W., Hopkins, D. B., and Foster, H. L., 1963, Pingos in central Alaska [abs.] : Geol. Soc. America Spec. Paper 73, p. 173.

Matzko; J. J., Jaffe, H. W., and Waring, C. L.; 1958, Lead-alpha age determinations of granitic rocks from Alaska : Am. Jour. Sci., v. 256, no. 8, p. 529-539.

Mertie, J. B., Jr., 1937, The Yukon-Tanana region, Alaska : U.S. Geol. Survey Bull. 872, $276 \mathrm{p}$.

Prindle, L. M., 1909, The Fortymile quadrangle, Yukon-Tanana region, Alaska : U.S. Geol. Survey Bull. 375, 52 p.

Wasserburg, G. J., Eberlein, G. D., and Lamphere, M. A., 1963, Age of the Birch Creek Schist and some batholithic intrusions in Alaska [abs.]: Geol. Soc. America Spec. Paper 73, p. 258-259. 